\title{
電子情報通信学会に関連する賞を 受賞された方を御紹介します。
}

\section{平成 19 年 フェロー称号}

2007年新フェロ一称号を贈呈された方は学会全体で49名でした.

基礎・境界ソサイエティ推薦で新フェローになられた6名の方々を御紹介します。

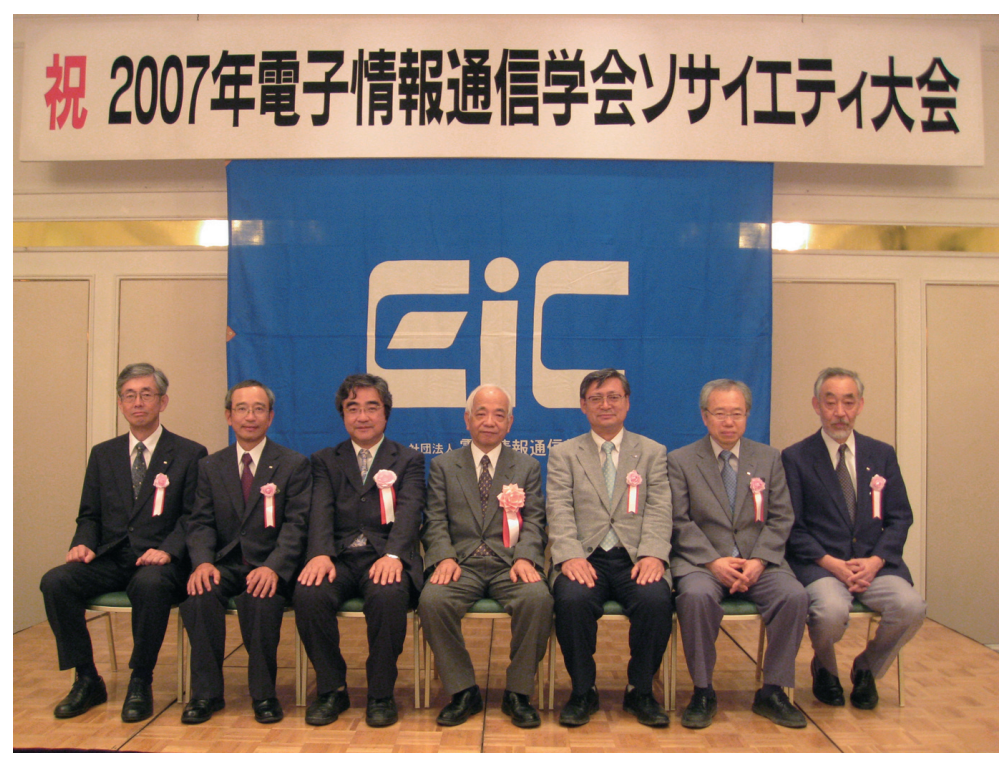

贈呈式にて (9月11日 鳥取大学)

左から, 築山さま, 小野寺さま, 大石さま (ソサイエティ会長), 富永さま(学会会長), 櫛引さま, 中島さま, 長島さま(牧野さまは御欠席でした).

小野寺 秀俊

「集積回路の物理設婷技術に関寸る先駆的研究」

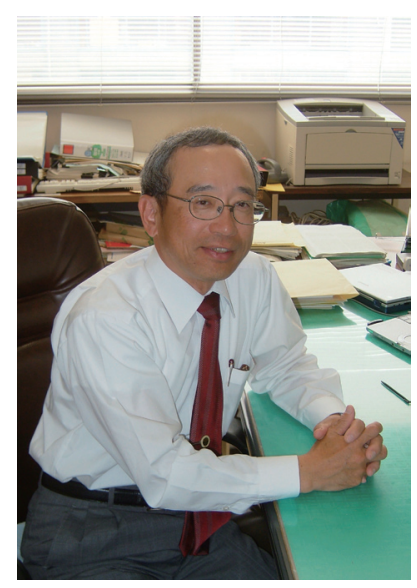

Q. フェローになられた御感想をお聞かせ下さい.

これまでの教育研究内容を評価頂けたことを大变うれしく思っています。多くの方に御指導頂 いたおかげですし，指導した学生諸君からも限りない刺激を受けました。すべての方々に感謝し ています

Q. 現在, 御興味をもたれている研究テーマを教えて下さい.

集積回路の微細化がナノスケールまで進んだ状況では, 各デバイスの特性ばらつきが増え，信頼性も劣化してい きます．これまでは，デバイス動作の完全性を前提に集 積回路は設計されていましたが, その前提が崩れること が予想されます，デバイスの動作に不確実性があっても， 確実に動作する集積回路を設計する技術に興味を持って います。

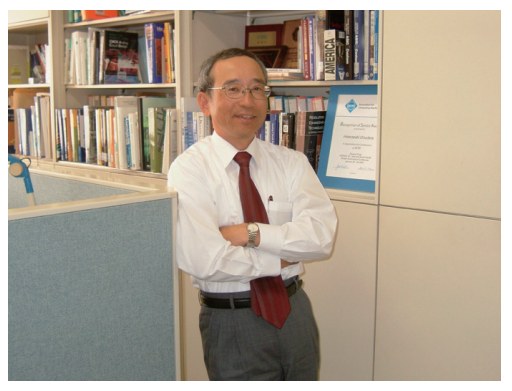




\section{Q. 今後の抱負をお聞かせ下さい.}

集積回路は, それが可能とするサービスにより, 人間の生活様式や文化をも变えていく 力があります。集積回路設計技術の教育研究を通じて, 未来社会のグランドデザインに少 しでもかかわっていきたいと考えています．

Q. 若い研究者の方へのメッセージをどうぞ!

私は大学院卒業後に専門分野を変え, 多くの人々に御指導頂きました. 自分から積極的 に働きかけ，いろいろな分野の勉強をするとともに，常に刺激のある環境となるように心

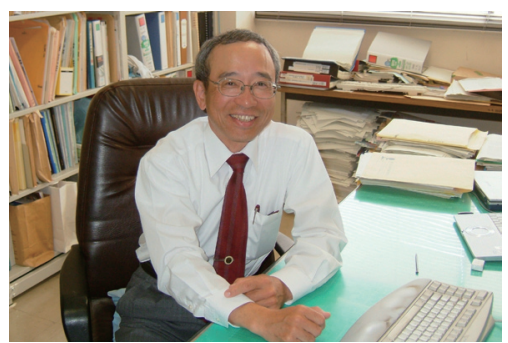
がけてください、私もできる限りお手伝いしたいと思います。

\section{櫛引淳一}

「超音波アイクロスペクトロスコピーと材料粹洒法の開発」

\section{Q. フェローになられた御感想をお聞かせ下さい.}

研究を始めてから早いものでもう30年以上になってしまいました。これまでの積み重ねが少しは中身 のある形になったのかと感じております。この間, 御指導頂いた先生, お世話になった先輩の方々, 一緒 に研究した学生達, そして今回のフェローへの推薦作業をしていただいた超音波研究会の関係者の方々, 皆様に心から感謝致します.

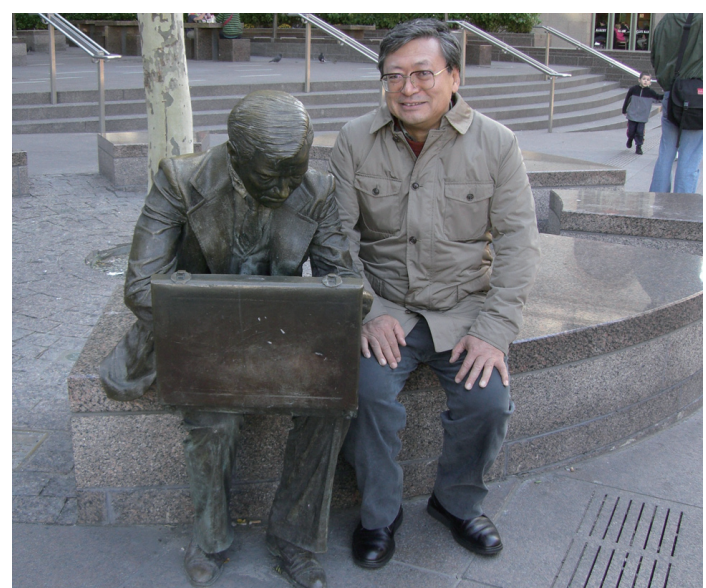

\section{Q. 今後の抱負をお聞かせ下さい.}

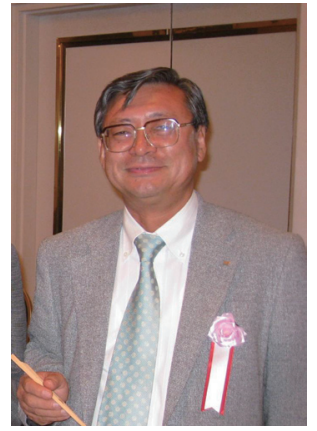

本研究の成果は音響特性を超精密に定量計測できるようにした結果です が，従来の材料評価技術では解決できなかつた問題を解いて，その有用性を 実証し, 専門分野では認知して頂いたと考えております。しかし, 評価技術 そのものが黒子的存在ですので, 材料科学の分野のユーザに広く認知という にはまだほど遠く, まだまだ時間がかかりそうです，今後, 研究者の方々に 使用して頂けるような実用機を開発し, 本技術を残したい)思っております

\section{策山修治}

「グラフ理埨を用いたコしピュー夕援用設㹁手法の研究」

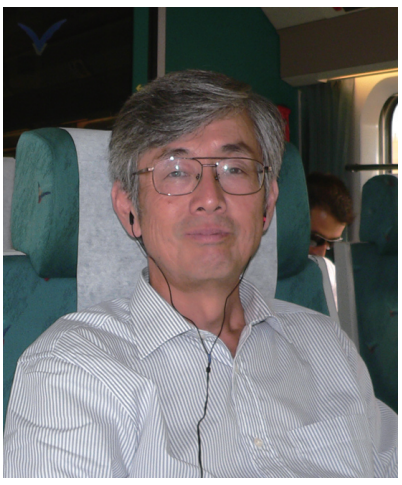

Q. フェローになられた御感想をお聞かせ下さい.

この度は, 思いがけなくフェローの称号を頂くことになり, 大変光栄に存じます，また, 推薦 の労をとって頂いた方や評価頂いた方々には感謝の念に絶えません．グラフ理論という EDA の 分野ではいささか古い響きの語が付いたテーマで称 号を頂くことになりましたが，依然，大規模回路の アルゴリズムを考える際には, グラフ理論の提供す る効率的アルゴリズムのお世話になっています。.

\section{Q. 現在, 御興味をもたれている研究テーマを教え て下さい.}

集積回路における配線遅延や製造ばらつきに興味を持っています，そのため，伝 達関数の極や正規分布の確率密度関数なども道具として使うようになりました。し かし，問題の整理の仕方など，研究の方法論は，グラフ理論を用いていた頃と余り 変わらないようです。

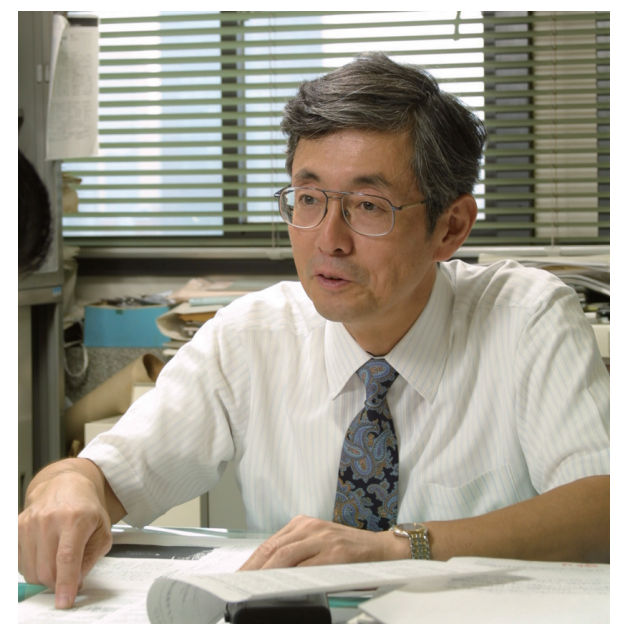




\section{Q. 今後の抱負をお聞かせ下さい.}

集積回路設計技術の研究には八ードとソフトの両方の知識を必要とするため, 私 の知的好奇心をいつまでも刺激してくれます。これからも新たな道具と古い（?）道 具を有効に組み合わせて, 効率的で有用な設計ツールの構築に取り組んで行きたい と思っています

Q. 若い研究者の方へのメッセージをどうぞ！

何かを成し遂げるためには，自分で自分の道を閉ざすようなことを言うべきでな いと, つくづく感じるようになりました。

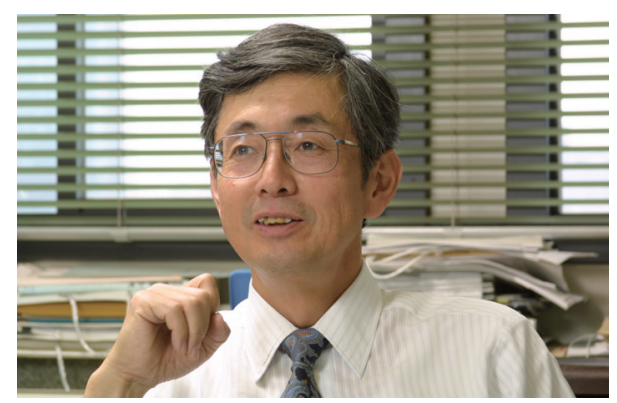

中島康治

「りりトレ, 二ューラルネットワーク等, 非缐形問題の研究」

\section{Q. フェローになられた御感想をお聞かせ下さい.}

名誉な称号をいただき，御推薦頂いた方々に感謝申し上げます。非線形問題との かかわりはソリトンからですが，常に新しい話題が顔を出す興味あふれる非線形の 分野においてフェローを頂けたことを大変うれしく思っております.

\section{Q. 現在, 御興味をもたれている研究テーマを教えて下さい,}

バースト発振などの能力を持つアクティブなユニットが多数結合して, その結果 として可能となる情報処理のシステムに関心があります．統計的観点に重点をおく いわゆるニューラルネットワークよりは, 各ユニットがアクティブデバイスという 点で非線形問題に軸足がある側面からの研究を進めたいと思っています。
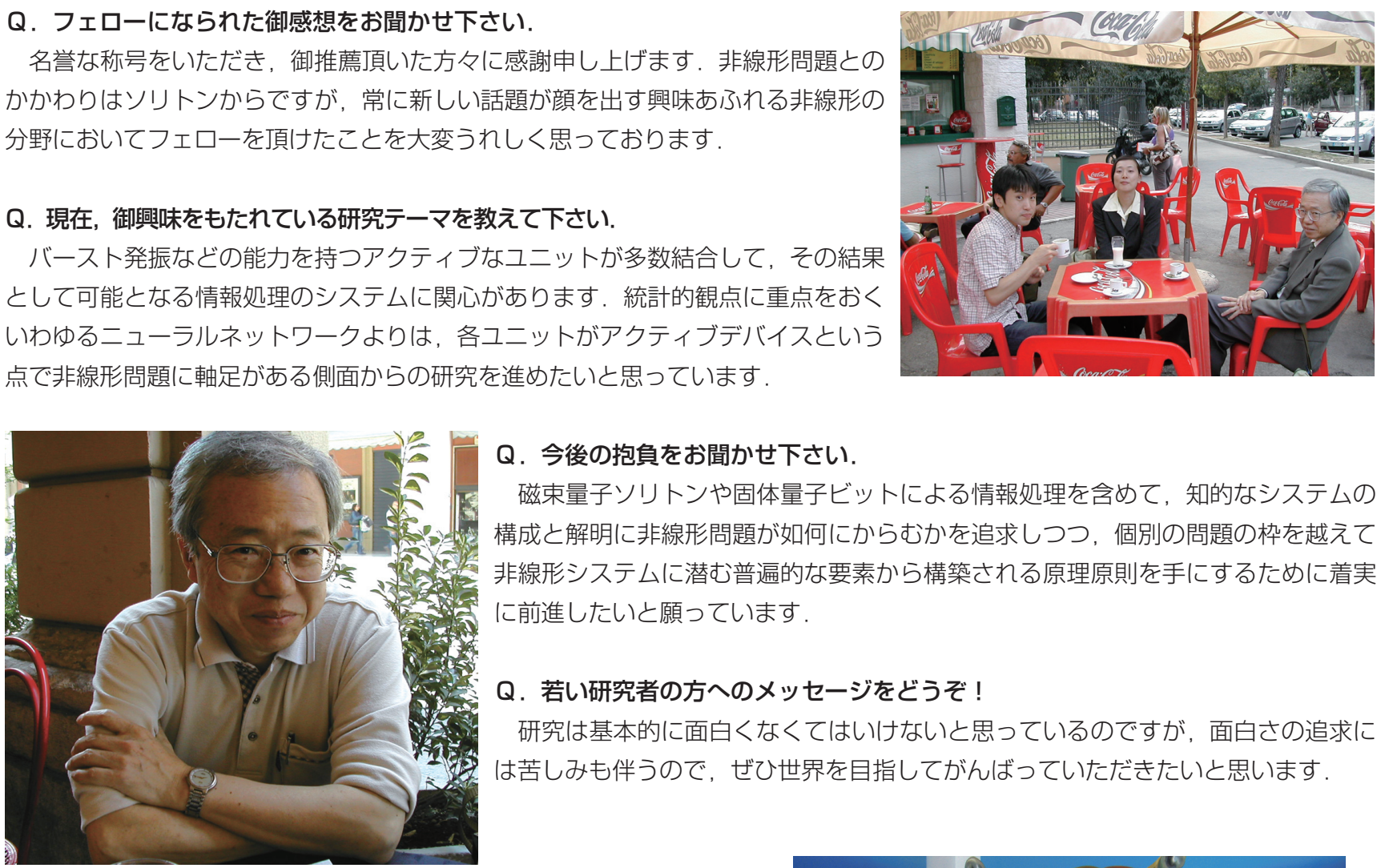

\section{Q. 今後の抱負をお聞かせ下さい.}

磁束量子ソリトンや固体量子ビットによる情報処理を含めて, 知的なシステムの 構成と解明に非線形問題が如何にからむかを追求しつつ, 個別の問題の枠を越えて 非線形システムに潜む普遍的な要素から構築される原理原則を手にするために着実 に前進したいと願っています。

Q. 若い研究者の方へのメッセージをどうぞ！

研究は基本的に面白くなくてはいけないと思っているのですが, 面白さの追求に は苦しみも伴うので，ぜひ世界を目指してがんばっていただきたいと思います。

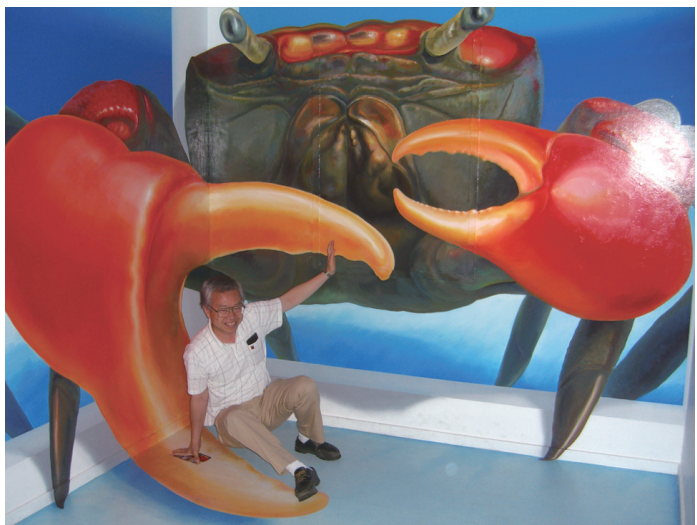


長島知区

「力オスの実用的特徵付け手法の開発と艺の応用に関寸る研究」

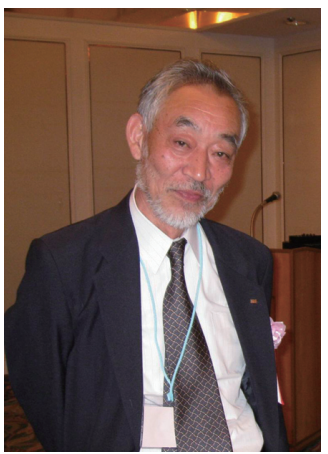

Q. フェローになられた御感想をお聞かせ下さい.

大変光栄なことで, 今までお世話になった関係の皆様に感謝してい ます．

Q. 現在, 御興味をもたれている研究テーマを教えて下さい.

勤務先大学の事情で, ここ10年ほど, もつぱら「感性工学」という新しい分野に関わってきました. そのため申し訳ないことですが, 非線形問題研究会からは遠ざかっていました。感性工学は理性を中心 とした知性から, 人間の感性に焦点をあてた脳の研究が核になるもので, 今後は非線形問題と感性工学, より広く生命情報工学の接点の研究を進めたいと考えています。

\section{Q. 今後の抱負をお聞かせ下さい.}

上の研究など, 狭い意味での非線形問題の研究と少し距離を置いたところ から, 本学会, 特に非線形問題研究の発展にお役にたてればと願っています. 杞憂であればよいのですが, 大学法人化の影響がここにきて, 非常に強く 出てきているのではないでしょうか? 非線形問題のような基礎的分野の研 究が大変困難な状況が生まれるのでないかと危惧しています.

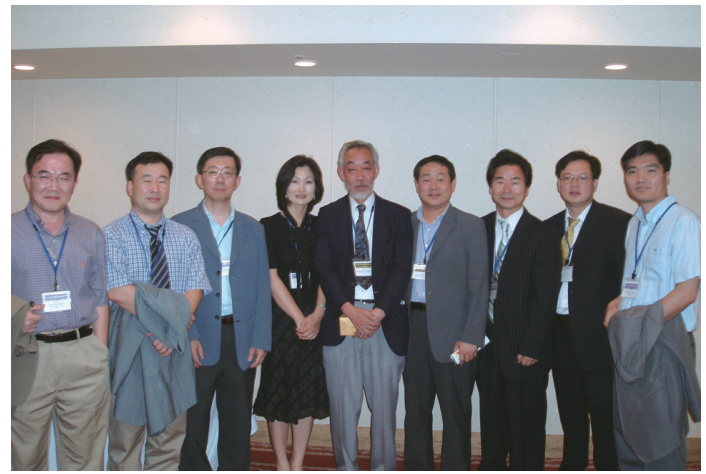

\section{牧野昭二}

「適応フイルタの研究およで音響信号処理技術の研究開発」

\section{Q. フェローになられた御感想をお聞かせ下さい.}

御推薦頂いた方々に感謝致します。これまで一緒に研究・開発を行ってきた方々など, 良い環境に恵まれたおかげだと思います。適応フィルタや適応アルゴリズムを題材とした 適応信号処理の研究と, 音響エコーキャンセラやブラインド音源分離を題材とした音響シ ステムの開発という２本の柱をバランスよく打ち立てることに專念してきました。 その功 績を認めて頂き，たいへんうれしく思います。

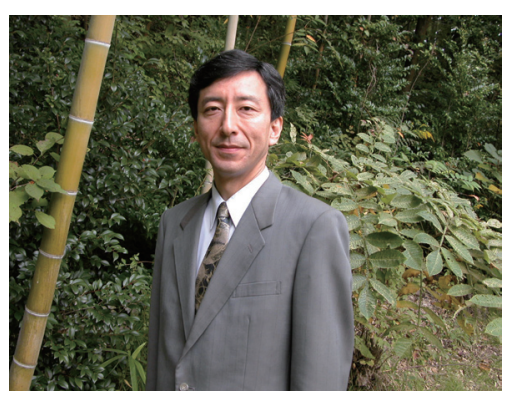

\section{Q. 今後の抱負をお聞かせ下さい.}

今後は，若い人たちや周りの人たちのために働きたいと思います。

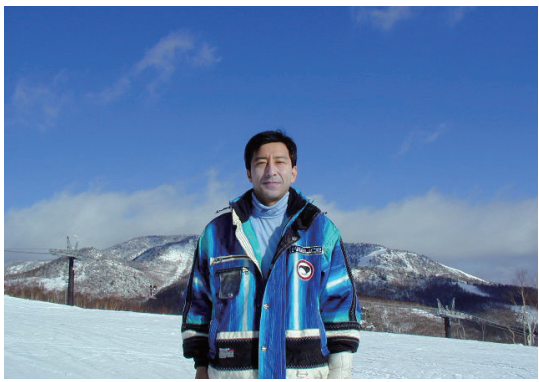

\section{Q．若い研究者の方へのメッセージをどうぞ！}

研究は過去の研究遺産を引き継ぎ、コミュニティ全体の共同作業で発展させ，後世に 残すものだと思います. 研究コミュニティとの give \& take の関係を大切にして欲し いと思います。また, 理論と応用のバランス感覚を持って欲しいと思います。 